\title{
Pelatihan Perancangan Kuis dan Video Pembelajaran Interaktif, Sebagai Upaya Peningkatan Kompetensi Pedagogik Guru SLTPN 7 Kota Payakumbuh
}

\author{
Elvi Rahmi ${ }^{*}{ }^{1}$, Efni Cerya ${ }^{2}$ \\ ${ }^{12}$ Pendidikan Ekonomi/ Fakultas Ekonomi/ Universitas Negeri Padang \\ ${ }^{*}$ Corresponding author, $\equiv$ Evirahmi83@fe.unp.ac.id
}

Revisi 10/11/2019;

Diterima 10/12/2019

Publish 10/01/2020
Kata kunci: Kuis, Video Pembelajaran, lectora inspire, quiz maker

\begin{abstract}
Abstrak
Pemanfaatan teknologi digital dalam pembelajaran di SLTPN 7 Kota Payakumbuh masih belum maksimal, baik sebagai media pembelajaran maupun untuk evaluasi. Metode yang dilakukan dalam pelatihan ini dimulai dengan orientasi materi, setelah dicapai kesepakatan maka pada saat pelatihan diberikan pemaparan mengenai konsep media, evaluasi dan prosedur bagaimana memanfaatkan aplikasi media pembelajaran interaktif (lectora inspire) dan aplikasi kuis (quiz maker). Setelah tahap pemaparan dilanjutkan dengan diskusi dan tanya jawab mengenai tata cara penggunaan aplikasi lectora inspire dan quiz maker. Tahap berikutnya adalah latihan terbimbing, latihan mandiri dan ditutup dengan evaluasi. Hasil yang diperoleh dari pelatihan ini adalah guru-guru di SLTPN 7 Kota Payakumbuh bisa mendapatkan pengetahuan, keterampilan, dan pengalaman dalam menggunakan aplikasi lectora inspire dan quiz maker yang berguna untuk meningkatkan kualitas pembelajaran.
\end{abstract}

\section{PENDAHULUAN}

\section{Analisis Situasi}

Pendidikan yang bermutu akan berkontribusi besar dalam kemajuan suatu bangsa, dimana mutu pendidikan sangat dipengaruhi oleh kualitas pembelajaran yang dilakukan oleh seorang guru. Kompetensi dan kualifikasi merupakan syarat penting yang harus dimiliki oleh seorang pendidik. Sejalan dengan hal ini pemerintah telah mengeluarkan undang-Undangundang Nomor 14 Tahun 2005 terkait kompetensi guru. Kompetensi guru dapat dimaknai sebagai kebulatan pengetahuan, keterampilan dan sikap yang berwujud tindakan cerdas dan penuh tanggung jawab dalam melaksanakan tugas sebagai agen pembelajaran. Kompetensi yang diharapkan dimiliki oleh setiap guru meliputi kompetensi professional, kompetensi pedagogik, kompetensi personal dan kompetensi sosial. Kemampuan guru dalam memfasilitasi pembelajaran yang menyenangkan merupakan bagian dari kompetensi pedagogik yang harus 
dikuasai guru. Kompetensi pedagogik penting untuk ditingkatkan, karena dengan peningkatan kompetensi pedagogik guru akan memiliki kemampuan untuk mengelola pembelajaran menjadi lebih baik, Rahman dalam Tyagita, B. P. A., \& Iriani, A. (2018). Kemampuan yang harus dimiliki guru berkenaan dengan aspek-aspek pedagogik diantaranya meliputi penguasaan terhadap karakteristik peserta didik dari aspek fisik, moral, sosial, kultural, emosional dan intelektual. Penguasaan terhadap teori belajar dan prinsip-prinsip pembelajaran yang mendidik. Mampu mengembangkan kurikulum yang terkait dengan bidang pengembangan yang diampu. Menyelenggarakan kegiatan pengembangan yang mendidik. Memanfaatkan teknologi informasi dan komunikasi untuk kepentingan penyelenggaraan kegiatan pengembangan yang mendidik.

Teknologi informasi bisa dimanfaatkan oleh guru untuk merancang kuis dan media pembelajaran. Pemanfaatan media yang relevan di dalam kelas dapat mengoptimalkan proses pembelajaran. Bagi guru dengan memanfaatkan media pembelajaran akan membantu dalam mengkonkritkan konsep atau gagasan yang disampaikan kepada siswa dan membantu memotivasi mereka untuk belajar. Bagi siswa, media dapat menjadi jembatan untuk berpikir kritis, siswa bisa jadi lebih mudah memahami, karena guru menyampaikan materi tidak hanya secara verbal. Agar media pembelajaran dapat termanfaatkan dengan baik, guru perlu mengetahui kebutuhan pembelajarannya dan permasalahan- permasalahan yang dihadapi siswa terkait materi yang akan diajarkan. Media perlu dikembangkan berdasarkan relevansi, kompetensi dasar, materi dan karakteristik siswa. Guru diharapkan bisa berperan sebagai kreator yaitu menciptakan dan memanfaatkan media yang tepat, efisien, dan menyenangkan bagi siswa.

Lectora inspire adalah produk teknologi yang bisa dimanfaatkan untuk pembelajaran, aplikasi ini dikembangkan oleh Perusahaan Trivantis Corporation. Lectora inspire merupakan salah satu program aplikasi yang dapat digunakan untuk membuat presentasi maupun media pembelajaran, aplikasi ini juga mudah untuk digabungkan dengan aplikasi lain,contohnya adalah quiz maker (aplikasi yang bisa digunakan untuk pembuatan kuis secara digital). Keunggulan lectora inspire bersifat user friendly (mudah digunakan) karena tidak membutuhkan kemampuan untuk memahami bahasa pemrograman yang rumit.(Zuhri \& Rizaleni, 2016). Lectora inspire menyediakan template yang siap digunakan untuk memasukkan materi pembelajaran, selain itu di dalam library Lectora inspire sudah terdapat banyak gambar, animasi, karakter animasi yang dapat kita gunakan secara langsung. Dengan menggunakam lectora inspire, materi pelajaran bisa didesain semenarik mungkin, dengan menggunakan video, serta gambar-gambar animasi yang berhubungan dengan materi pelajaran Shalikhah, N. D. (2017).

Pemanfaatan teknologi pembelajaran masih belum merata disemua sekolah. Observasi di SLTPN 7 Kota Payakumbuh memberikakan informasi bahwa penggunaan teknologi pembelajaran di sekolah ini masih belum maksimal. Guru-guru di sekolah ini masih sangat mengandalkan metode ceramah dalam pembelajaran. Media yang digunakan guru masih cenderung sederhana dan kurang menarik (hanya power point) yang berisi uraian materi. Disamping masih rendahnya pemanfaatan media dalam pembelajaran juga diketahui bahwa untuk pelaksanaan evaluasi baru dilakukan secara manual belum memanfaatkan 
perkembangan teknologi. Berdasarkan hasil diskusi tim pengabdi dengan perwakilan guru SLTPN 7 Kota Payakumbuh, mereka berharap adanya pelatihan yang diberikan oleh tim pengabdi terkait dengan perancangan kuis dan media pembelajaran yang bersifat interaktif. Pelatihan ini mereka anggap sangat dibutuhkan karena mayoritas guru belum mampu memanfaatkan secara optimal perkembangan teknologi pembelajaran. Menanggapi masalah ini maka dipandang perlu untuk memberikan pelatihan pemanfaatan teknologi digital dalam pembelajaran terutama untuk merancang media dan kuis pembelajaran yang menarik. Dengan pelatihan yang diberikan diharapkan kompetensi guru dalam merancang media dan kuis pembelajaran akan meningkat sehingga bermuara terhadap peningkatan kualitas pembelajaran

\section{Solusi dan Target}

Permasalahan yang dihadapi oleh guru-guru di SLTPN 7 Kota Payakumbuh belum memanfaatkan teknologi pembelajaran secara maksimal, hal ini karena keterbatasan pengetahuan dan keterampilan yang dimiliki. Solusi yang direncanakan oleh tim pengabdi adalah dengan cara memberikan pelatihan secara terpadu kepada guru mengenai pemanfaatan teknologi dalam pembelajaran terutama mengenai perancangan evaluasi pembelajaran (kuis) dan video pembelajaran yang interaktif ,dengan menggunakan aplikasi digital yaitu lectora inspire dan quiz maker, tahapan-tahapan yang dilakukan dalam pelatihan ini adalah sebagai berikut :

1. Penulisan modul pembuatan kuis dan media pembelajaran berbasis multi media, yang dibagi atas beberapa materi :

a. Materi 1 berisi tentang konsep kuis dan media pembelajaran

b. Materi 2 berisi tentang Proses pembuatan Media pembelajaran berbasis multimedia (interaktif) yang terdiri atas beberapa tahap : Tahap awal adalah need assessment dan brainstorming, tahap kedua, storyline dan storyboard, tahap kedua ini berupa penuangan ide, konsep, dan tujuan pencapaian pembelajaran ke dalam struktur menu dan tahap ke 3 mengenai pengumpulan data, produksi dan terakhir adalah tahap publikasi.

c. Materi 3 berisi pengenalan dan prosedur dalam pemanfaatan aplikasi lectora inspire sebagai media pembelajaran interaktif

d. Materi 4 berisi Pengenalan dan langkah langkah memanfaatkan aplikasi quiz maker untuk pelaksanaan evaluasi/ kuis dalam pembelajaran

2. Penyajian materi sesuai dengan isi modul. penyajian dilakukan dengan metode ceramah dibantu dengan multi media, dilengkapi dengan diskusi dan tanya jawab.

3. Latihan terbimbing, sesuai dengan contoh yang ada, kegiatan ini dipandu oleh instruktur

4. Latihan mandiri, peserta mengerjakan sendiri pembuatan video pembelajaran dan kuis pembelajaran sesuai dengan mata pelajaran yang mereka ampu

5. Pendampingan, setelah pelatihan berakhir, bagi peserta yang mengalami kendala, peserta bisa berkonsultasi, baik secara langsung atau melalui telepon.

Kegiatan pengabdian masyarakat ini dilaksanakan mulai dari tahap orientasi pada tanggal 26 Agustus 2019 dan berakhir pada tanggal 13 September 2019, dimana hari terakhir pertemuan, peserta melakukan pengumpulan tugas mandiri dan dilakukan evaluasi kegiatan pengabdian. Pelatihan pengabdian masyarakat ini dilaksanakan di SLTPN 7 kota Payakumbuh dan peserta pelatihan adalah seluruh guru dan tenaga kependidikan yang ada di sekolah tersebut yang berjumlah $+/-23$ orang. 
Target yang diharapkan dari kegiatan ini adalah terjadinya peningkatan kemampuan guru SLTPN 7 Kota Payakumbuh dalam: 1) Memahami konsep dan teknik penggunaan aplikasi quiz maker yang bisa digunakan untuk perancangan kuis, dan aplikasi lectora inspire yang bisa digunakan untuk perancangan video pembelajaran interaktif 2) Menyelesaikan contoh pembuatan kuis dan video pembelajaran yang ada dengan menggunakan quiz maker dan Lectora inspire Pada akhir latihan diharapkan 80\% langkahlangkah perancangan kuis dan video bisa dikerjakan dengan baik dan benar oleh guru. 3) Mengaplikasikan pengetahuan yang didapatkan dalam merancang kuis digital dan video interaktif sebagai alat bantu pembelajaran. pada akhir kegiatan diharapkan guru mampu mengaplikasikan dengan benar materi ini dan bisa menghasilkan produk media sesuai dengan bidang ilmu dan mata pelajaran yang mereka ampu. Artinya diharapkan sebahagian besar guru telah memiliki pengetahuan dan keterampilan dalam menggunakan aplikasi lectora inspire dan quiz maker sebagai bentuk tanggung jawab dalam peningkatan kompetensi pedagogiknya selaku seorang guru.

\section{METODE PELAKSANAAN}

Pelatihan perancangan kuis dan video pembelajaran interaktif ini dilaksanakan di SLTPN 7 Kota Payakumbuh Sumatera Barat. Pelaksanaan pengabdian berlangsung sejak tanggal 26 Agustus 2019 sampai tanggal 13 September 2019. Metode pelaksanaan pengabdian dimulai dengan: 1) Orientasi materi, dimana materi yang telah disusun dikonfirmasikan kepada perwakilan mitra pengabdian, hal ini untuk melihat kesesuaian antara kebutuhan guru- guru di SLTPN 7 Kota Payakumbuh dengan materi pelatihan yang dirancang, 2) Pemberian Informasi/ceramah mengenai konsep media dan pemanfaatan aplikasi lectora inspire dan quiz maker untuk kuis digital dan media pembelajaran interaktif. 3) Diskusi dan tanya jawab, kegiatan ini dilakukan sembari memberikan materi, dimana guru guru bisa bertanya serta berdiskusi jika ada hal yang mereka ragukan terkait materi yang disampaikan 4) Latihan terbimbing, pada tahap ini guru mencobakan untuk merancang media dan kuis dengan menggunakan aplikasi lectora inspire dan quiz maker 5) Latihan Mandiri. Tahap ini guru-guru merancang secara mandiri pembuatan media dan kuis pembelajaran digital mulai dari tahap need assessment, story board, penuangan ide, dan produksi. 6) Evaluasi, evaluasi dilakukan secara lisan (diskusi) dengan peserta pelatihan terkait pelaksanaan kegiatan, disamping itu peserta juga diminta mengisi angket pelaksanaan pelatihan yang dilakukan.

\section{HASIL DAN PEMBAHASAN}

Pelaksanaan pelatihan perancangan kuis dan video pembelajaran interaktif ini dilaksanakan selama hampir 3 minggu yakni dari tanggal 26 Agustus 2019 sampai pada tanggal 13 September 2019. Pelaksanaan pelatihan menggabungkan pertemuan secara online dan tatap muka secara langsung.

Dari hasil pelatihan didapat hasil adanya peningkatan pengetahuan dan keterampilan guru SLTPN 7 Kota payakumbuh dalam merancang kuis dan video pembelalajaran 
interaktif. Pada akhir pelaksanaan pelatihan dilakukan evaluasi, dimana kepada guru diberikan angket mengenai tanggapan mereka terkait pelaksanaan pelatihan yang dilakukan.

Tabel 1. Angket Penelitian

\begin{tabular}{|c|l|l|l|l|l|}
\hline No. & \multicolumn{1}{|c|}{ Pernyataan } & STS & TS & S & SS \\
\hline 1 & $\begin{array}{l}\text { Materi Pembuatan Video Pembelajaran Interaktif } \\
\text { sesuai dengan kebutuhan Bapak/ibu }\end{array}$ & & & & \\
\hline 2 & $\begin{array}{l}\text { Materi Pembuatan Video Pembelajaran Interaktif } \\
\text { menarik untuk digunakan dalam pembelajaran }\end{array}$ & & & & \\
\hline 3 & $\begin{array}{l}\text { Materi Pembuatan Video Pembelajaran Interaktif } \\
\text { berguna untuk menunjang pembelajaran }\end{array}$ & & & & \\
\hline 4 & $\begin{array}{l}\text { Narasumber menyampaikan Materi Pelatihan } \\
\text { pembuatan video mudah untuk dipahami }\end{array}$ & & & & \\
\hline 5 & $\begin{array}{l}\text { Narasumber menyampaikan Materi Pelatihan } \\
\text { pembuatan video dengan cara yang menarik }\end{array}$ & & & & \\
\hline 6 & $\begin{array}{l}\text { Waktu pelaksanaan Materi Pelatihan pembuatan } \\
\text { video pembelajaran telah cukup memadai }\end{array}$ & & & & \\
\hline
\end{tabular}

Sumber : Data Primer 2019

Dari hasil Tanggapan yang diberikan guru, didapat data sebagai berikut:

Materi Pembuatan Video Pembelajaran Interaktif Sesuai dengan kebutuhan

Bapak/lbu

9 tanggapan

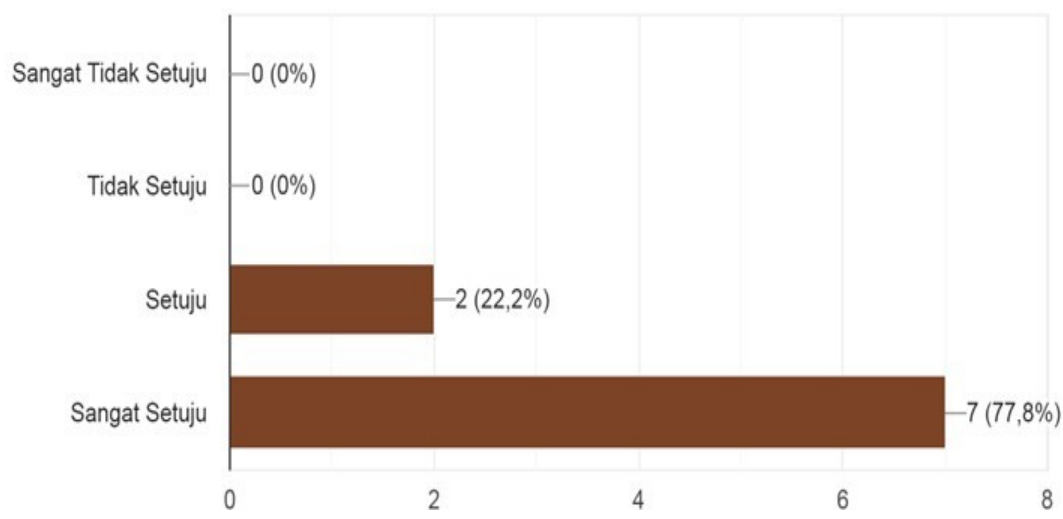

Gambar 1. Tanggapan dari Guru terkait Kesesuaian Materi Pelatihan dengan Kebutuhan 
Gambar 1 di atas, melihatkan bahwa $77.8 \%$ guru berpendapat sangat setuju bahwa materi yang diberikan dalam pelatihan sesuai dengan kebutuhan mereka, dan ada 22,2\% guru menilai setuju. Tingginya tingkat kesetujuan ini karena materi pelatihan yang diberikan telah diorientasikan sebelumnya kepada perwakilan guru sehingga materi bisa sesuai dengan kebutuhan yang guru rasakan dalam pembelajaran di sekolah.

\section{Materi Pembuatan Video Pembelajaran Interaktif menarik dengan kebutuhan Bapak/lbu \\ 9 tanggapan}

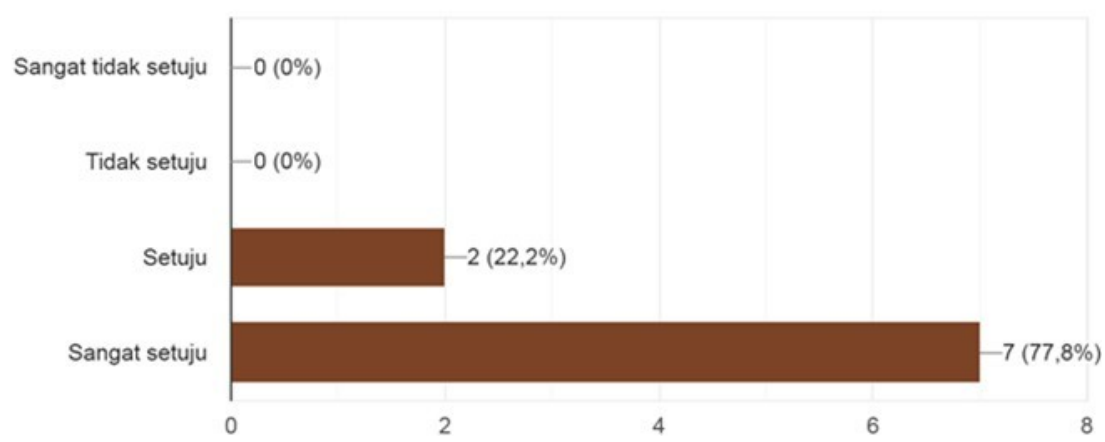

Gambar 2 . Tanggapan dari Guru terkait Kemenarikan Materi

Gambar 2 di atas melihatkan bahwa $77.8 \%$ guru berpendapat sangat setuju bahwa materi yang diberikan dalam pelatihan menarik bagi mereka, dan ada 22,2\% guru menilai setuju. Tingginya tingkat kesetujuan ini karena materi pelatihan yang diberikan disesuaikan dengan perkembangan teknologi pembelajaran dimana banyak dari guru belum menggunakan teknologi pembelajaran yang terkini.
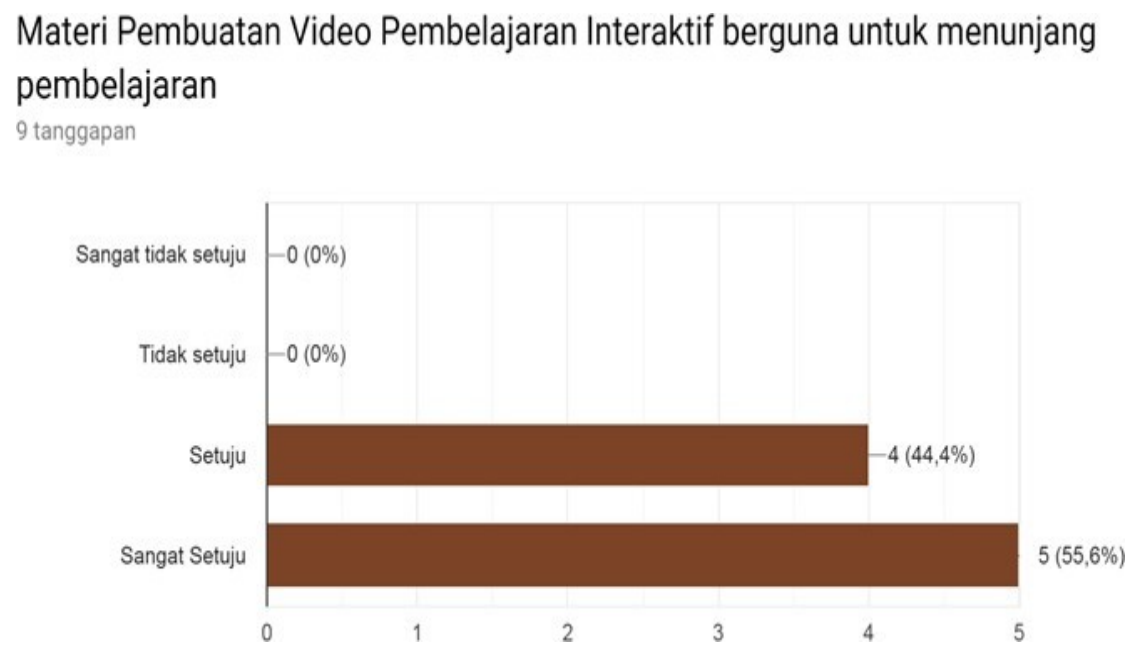

Gambar 3. Tanggapan dari Guru terkait Kebermanfaatan Materi 
Gambar 3 di atas melihatkan bahwa $55.6 \%$ guru berpendapat sangat setuju bahwa materi yang diberikan dalam pelatihan berguna bagi mereka dalam melaksanakan pembelajaran, dan ada 22,2\% guru menilai setuju. Tingginya tingkat kesetujuan ini karena materi pelatihan yang diberikan disesuaikan dengan perkembangan teknologi pembelajaran dimana banyak dari guru belum memanfaatkan dengan optimal teknologi pembelajaran yang terkini. Dengan adanya pelatihan pemanfaatan aplikasi lectora inspire dan quiz maker ini maka bisa menunjang variasi media pembelajaran dan kuis yang dirancang oleh guru.

Narasumber menyampaikan materi pelatihan pembuatan video mudah untuk dipahami

9 tanggapan

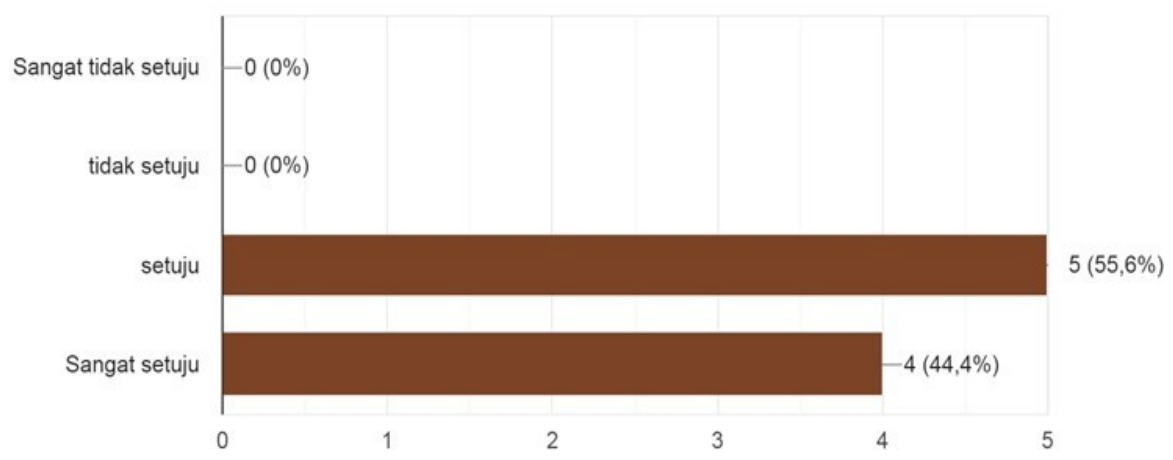

Gambar 4 . Tanggapan dari Guru Terkait Penyampaian dari Narasumber

Gambar 4 di atas melihatkan bahwa 44,46 \% guru berpendapat sangat setuju dan $55,6 \%$ setuju bahwa materi yang disampaikan oleh narasumber bisa mereka ikuti dengan baik karena mudah untuk dipahami. Pelatihan dilakukan dengan pemaparan tanya jawab dan diskusi, sehingga para guru -guru bisa lebih mudah memahami, karena jika ada hal yang mereka ragukan guru bisa langsung mengajukan pertanyaan.

\section{Narasumber menyampaikan materi pelatihan pembuatan video dengan cara yang menarik \\ 9 tanggapan}

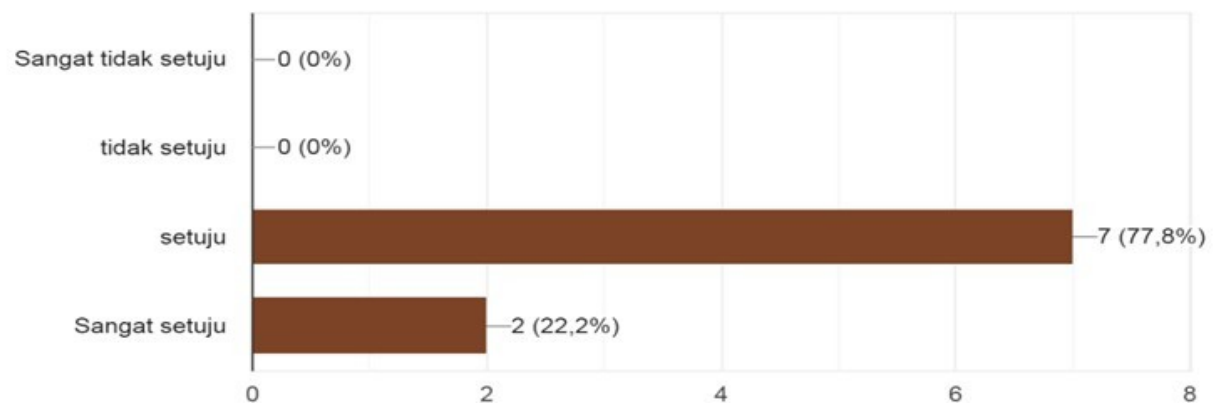




\section{Gambar 5. Kemenarikan Penyampaian dari Narasumbe}

Gambar 5 di atas melihatkan bahwa 22,2 \% guru berpendapat sangat setuju dan $77,8 \%$ setuju bahwa materi yang disampaikan oleh narasumber bisa menarik bagi guru. Pelatihan dilakukan dengan bahan presentasi yang menarik karena dilengkapi dengan video dan animasi yang bagus. Disamping itu agar materi tidak berjalan monoton, maka diselingi dengan hiburan, seperti bernyanyi bersama dan ice breaking.

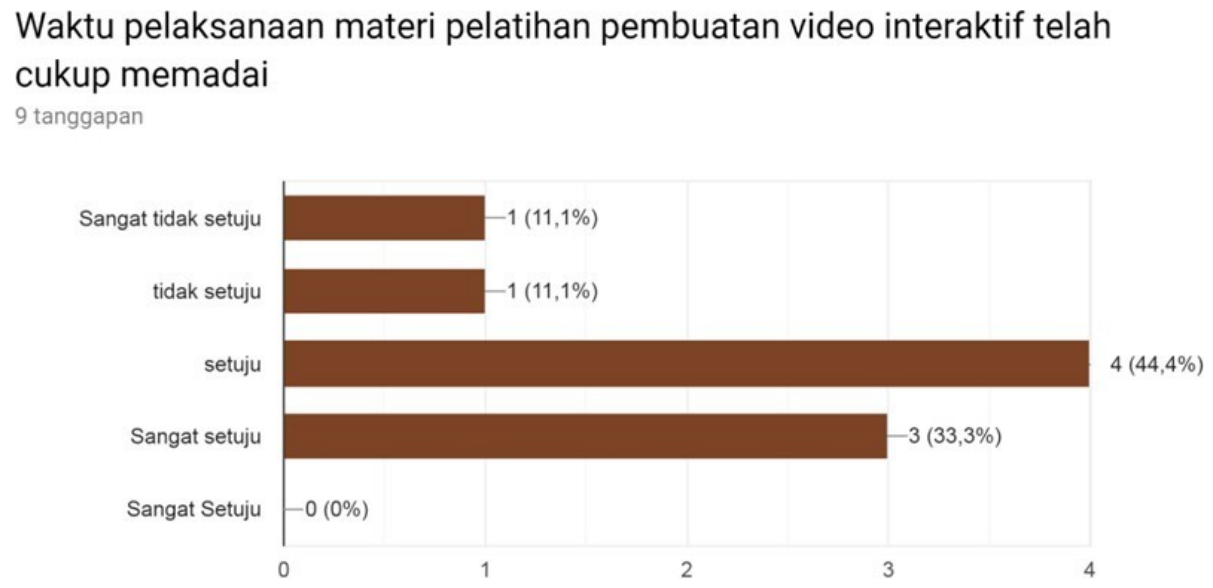

Gambar 6. Tanggapan Guru Terkait lama waktu pelatihan

Gambar 6 di atas melihatkan bahwa jawaban guru beragam terkait lama waktu pelatihan yang dibutuhkan agar guru bisa memiliki kemampuan dalam merancang media pembelajaran dalam bentuk video dan kuis pembelajaran. 33,3\% guru berpendapat sangat setuju bahwa waktu pelatihan yang diberikan memadai, dan $44,4 \%$ setuju bahwa waktu pelatihan yang diberikan sudah memadai, namun juga ada guru yang tidak setuju dan sangat tidak setuju dengan waktu pelatihan yang diberikan, hal ini karena ada guru yang sampai waktu pelatihan selesai mereka masih belum puas dengan waktu yang diberikan, untuk tim pengabdi menyampaikan bahwa guru- guru berhak bertanya atau berkonsultasi via wa atau email jika ada kesulitan dan hal yang ingin mereka tanyakan.

Pelaksanaan pelatihan media ini merupakan salah satu upaya meningkatkan kompetensi kompetensi pedagogik guru.dimana kompetensi pedagogik sesuai yang diatur dalam Peraturan Menteri Pendidikan Nasional No.16 tahun 2007, yang meliputi 10 Kompetensi Inti dan Kementrian Pendidikan Nasional Direktorat Jenderal Peningkatan Mutu Pendidik dan Tenaga Kependidikan (2010, 39-51)memuat beberapa subkompetensi yaitu, 1) menguasai karakteristik peserta didik dari aspek fisik, moral, sosial, budaya, kultural, emosional dan intelektual. 2) menguasai teori belajar dan prinsip-prinsip pembelajaran yang mendidik. 3) mengembangkan kurikulum yang berkaitan dengan mata pelajaran/bidang pengembangan yang diampu. 4) menyelenggarakan pembe- lajaran yang mendidik 5) memanfaatkan teknologi informasi dan komunikasi untuk kepentingan pembelajaran 6) memfasilitasi pengembangan potensi peserta didik dan membantu pengembangan potensi peserta didik untuk mengaktualisasikan berbagai potensi yang dimiliki. 7) berkomunikasi secara efektif, empatik, dan santun dengan peserta didik. 8) menyelenggarakan penilaian dan evaluasi proses dan hasil belajar. 9) memanfaatkan hasil 
penilaian dan evaluasi untuk kepentingan pembelajaran. 10) melakukan tindakan reflektif untuk peningkatan kualitas pembelajaran. Standar kompetensi pedagogik.

Perubahan dalam pola pembelajaran yang dilakukan oleh guru amat sangat dibutuhkan. Teknologi informasi dan komunikasi dalam pembelajaran berperan sebagai penghubung dalam pelaksanaan transfer ilmu pengetahuan tanpa sama sekali menghilangkan model awal pembelajaran yang berlangsung secara tatap muka di dalam kelas (Husain, C. (2014). Pemanfaatan teknologi informasi dan komunikasi dalam pembelajaran baik untuk media maupun evaluasi dilakukan dalam rangka meningkatkan efektifitas dalam pelaksanaan proses pembelajaran yang pada akhirnya diharapkan dapat meningkatkan hasil belajar siswa serta mutu individu para peserta didik.

\section{KESIMPULAN}

Kegiatan pengabdian masyarakat di SLTPN 7 Kota Payakumbuh dengan memberikan pelatihan terkait kuis dan media pembelajaran di nilai bermanfaat dimana respon dari guru menyatakan bahwa materi yang disampaikan menarik, sesuai dengan kebuthan guru dan bermanfaat dalam menunjang pembelajaran. Pelatihan yang diberikan juga meningkatkan pengetahuan, pemahaman dan keterampilan guru terkait pemanfaatan aplikasi lectora inspire dalam pembelajaran.

\section{DAFTAR PUSTAKA}

Husain, C. (2014). Pemanfaatan teknologi informasi dan komunikasi dalam pembelajaran di SMA Muhammadiyah Tarakan. Jurnal Kebijakan dan Pengembangan Pendidikan, 2(2).

Khofiatun, K., \& Ramli, M. (2016). Peran Kompetensi Pedagogik Guru Dalam Pembelajaran Tematik Di Sekolah Dasar. Jurnal Pendidikan: Teori, Penelitian, dan Pengembangan, 1(5), 984-988.

Listiaji, P. Pengembangan Apliaksi Mobile Learning sebagai Penunjang Pembelajaran Fisika pada Materi Hukum Gravitasi Newton untuk Siswa SMA, Semarang: Universitas Negeri Semarang;2015

Smaldino, E.S., Russel, J.D., Heinich, R., et al. (2004). Instructional Media and Technologies for Learning (8thEdition). New Jersey: Pearson Merril Prentice Hal

Shalikhah, N. D., Primadewi, A., \& Iman, M. S. (2017). Media Pembelajaran Interaktif Lectora Inspire Sebagai Inovasi Pembelajaran. Media Pembelajaran Interaktif Lectora Inspire Sebagai Inovasi Pembelajaran, 20(1), 9-16.

Tyagita, B. P. A., \& Iriani, A. (2018). Strategi Peningkatan Kompetensi Pedagogik Guru Untuk Meningkatkan Mutu Sekolah. Kelola: Jurnal Manajemen Pendidikan, 5(2), 165-176.

Wena, Made.(2009). Strategi Pembelajaran Inovatif Kontemporer. Suatu Tinjauan kosneptual Operasional, Jakarta : Bumi Aksara.

Zuhri, M.S., \& Rizaleni, E. A. (2016). Pengembangan Media Lectore Inspire dengan Pendekatan Kontekstual pada Siswa Kelas X. Pythgoras, 5(2), 113-119. 